\title{
The Effect of Fiscal Incentive on Earning Management among Listed Companies in Indonesia
}

\author{
Dyah Raras Danastri ${ }^{1}$, Christine ${ }^{1^{*}}$ \\ ${ }^{1}$ Faculty of Economics and Business, Universitas Indonesia, Depok 16424, Indonesia \\ *Corresponding Author: indivara_devi@yahoo.com
}

\begin{abstract}
This study aims to analyze how a fiscal incentive provided by the government to initiate investment will affect a company's earning management. The fiscal incentive used in this study is the corporate tax rate reduction for listed companies based on Government Regulation (GR) No. 81/2007 and GR No. 77/2013. The unbalanced panel data collected consists of 346 listed companies in the period of 2008-2014 excluding companies from the financial and mining sectors. Multivariate regression results show that there is no evidence that the tax rate reduction has any impact on the company's earning management.
\end{abstract}

Keywords: Earning Management; Corporate Tax Rate Reduction.

\section{INTRODUCTION}

Investment plays a crucial role in a country’s economic development. Capital placements by local and foreign investors through direct investments as well as capital markets create multiplier effects in the national economy. Some of the effects are providing work for the labor market, transferring technology and managerial skills, and generating revenue through corporate income tax. These great impacts encourage the government to create policies that support the investment climate. One such policy involves providing incentives in both non-fiscal and fiscal areas $^{1}$.

The Handbook of Facilities and Incentives of Indonesia's Income Tax $1^{\text {st }}$ and $2^{\text {nd }}$ Edition have listed all the tax facilities given to individual and corporate taxpayers. One of the facilities is the reduction in the corporate income tax rate for listed companies, as stated on Article 17 paragraph 2 of the Law No. 17/1983 which is regulated by GR No. 81/2007, which has since been amended to GR No. 77/2013 and GR No. 56/2015. A study done by Pamungkas $^{2}$ shows that there was an increase in the utilization of the facility over the period of 2008-2010. The same result is consistent with the data collected by Listed Company Tax Office (LCTO) for the fiscal year 20112014. When the policy was first implemented in 2011, there were only 60 companies receiving the tax rate reduction facility. By 2014, the number had increased to 85 out of 506 listed companies.

The tax rate reduction facility is not only a way to reduce company's cost, but can also benefit the company in terms of generating new capital by conducting an initial public offering (IPO) as well as a seasoned equity offering (SEO). However, IPO and SEO could be seen as an opportunity for a company to manage its earning in order to attract new investors ${ }^{3-6}$. Earnings management in the form of inflating net income to a certain amount before a capital offering is the most common form of earning management, although there are also some practices in which companies deflate their net income to make the shares underpriced ${ }^{7}$. Earnings management practices are mostly motivated by the urgency of management to comply with covenants, as well as the presence of compensations attributable to certain target net incomes ${ }^{5}$. Ideally, a company can reduce its costs and achieve the targeted net income by properly utilizing fiscal incentives; the more a company receives in fiscal incentive, the less it will engage in earning managements ${ }^{8}$. The utilization of fiscal incentives is less likely to be prone to future litigation issues than engaging in both real and accrual earnings management.

This research emphasizes the issue of how fiscal incentives offered by the government are believed to give a benefit in the economy in the macro scale, as well as in the scale of a company.

\section{LITERATURE REVIEW AND HYPOTHESIS DEVELOPMENT}

Fiscal policy in the form of a tax rate reduction has a greater impact on economic growth compared to other fiscal policies, such as the expansion of government spending ${ }^{9}$. Tax reduction generates a greater amount of savings that can be allocated for other uses, such as investments or increased consumption for both individual and corporate taxpayers. The growing number of investments and consumption leads to an increase in gross domestic 
product (GDP) and triggers growth in the national economy ${ }^{10-12}$. However, Edgerton ${ }^{13}$ found that companies are affected differently by the same tax incentive. The effects depend on the financial stability of each company and the current economic condition of the country. Moreover, if the taxation system in a country applies the loss carry forward concept, as is the case in Indonesia, then the tax facility will not have any impact on companies which experience losses.

A tax facility in the form of a corporate income tax rate reduction for listed companies is a facility that is exclusively given to support the capital market's role as a source of funding and to increase public participation in the market. Based on Article 17 Law No. 7/1983 on Income Taxes, which was amended with Law No. 36/2008, the tax reduction is $5 \%$ of the highest rate applicable for domestic corporate taxpayers. Other requirements that have to be fulfilled are as follows:

a. A minimum of $40 \%$ of total issued shares have to be traded in Indonesia Stock Exchange (IDX).

b. The traded shares are owned by a minimum of 300 individuals.

c. Each shareholder can only own less than $5 \%$ of total shares. and

d. The above requirements have to be maintained at least 183 days in 1 fiscal year.

To meet the requirement of public ownership, a company has to engage in IPO or SEO. The change of the company's structure from private to public creates different interests between management as the agent and shareholders as the principal as defined in agency theory ${ }^{14}$. Asymmetry of information is more likely to occur since the management has more access to the company's information than have the shareholders and this would affect the decision-making process. In presenting reports to shareholders, especially financial reports, the management has options to present certain aspects in the report as accepted by accounting standards ${ }^{15}$. Generally accepted accounting principles (GAAP) adhere to principle-based standards, which give the opportunity for management, as the preparer of financial reports, to use their discretion, or even manipulate certain accounts without affecting cash flow $^{16}$. In general, discretion is used to inflate net income since it commonly becomes the benchmark of a company’s performance. However, discretion can also be used to deflate profit for other purposes ${ }^{17}$.

The proxy that is used to measure earnings management is accrual discretionary. Accrual discretionary shows how management can move figures in accrual accounts, especially working capital, from one period to another ${ }^{17,18}$. Accrual discretionary is considered relevant since a company's income tax is based on accounting income; thus, any change in accruals will affect taxable income in the same direction ${ }^{19}$. The use of accrual discretionary in earnings management is more desirable in terms of cost because it does not have any effect on cash flow compared to real earnings management. Hence, it is easier and less costly for companies to conduct accrual earnings management $\mathrm{t}^{20-22}$.

$\mathrm{He}^{8}$ explains that the risk of earnings management activity is not limited to litigation, but also reputation in the long term. In addition, an early indication of earnings management which is detected by public or DGT will lead to inspections and investigations. It is also possible that the company will be charged with fines ${ }^{18}$. By utilizing tax reduction facility, company can reduce its tax payments and increase its net income without having to be exposed to the risks associated with earnings management. Based on this argument, the hypothesis proposed in this research is:

H1: The more tax facilities received by a company, the less it is indicated to engage in earnings management, ceteris paribus.

\section{RESEARCH METHOD}

This research uses secondary panel data collected from financial reports available on IDX's website and Datastream. For listed companies which received the tax facility, data is collected through their financial reports and from LCTO. Companies in the financial industry are excluded from sample since the industry has distinct characteristics and risk-profile from other industries. Companies in the mining sector are also excluded from sample because of lex specialis. The classification of industries used in the research refers to IDX Fact Book 2015. The data gathered is from fiscal year 2008 when GR No. 81/2007 first enacted to fiscal year 2014.

This research refers to similar research conducted by $\mathrm{He}^{8}$ for companies listed in Shenzhen Stock Exchange and Shanghai Stock Exchange in the period of 1997-2006. Based on the research, there are two proxies to measure the research variables, which are earnings management and fiscal incentives.

\section{Earnings Management}

Geraldina ${ }^{23}$ and $\mathrm{He}^{8}$ create a model to measure abnormal accruals that is based on modified Jones model. This modified model is used for estimating cross-section parameters so that it can generate abnormal accrual $(D A)$. With a further modification, the model to measure abnormal accruals that will be used in this research is as follows:

$$
\frac{T A C C_{i, t}}{A S_{i, t-1}}=\alpha_{0}+\alpha_{1}\left(\frac{1}{A S_{i, t-1}}\right)+\alpha_{2} \frac{\left(\Delta R E V_{i, t}-\Delta A R_{i, t}\right)}{A S_{i, t-1}}+\alpha_{3}\left(\frac{P P E_{i, t}}{A S_{i, t-1}}\right)+\varepsilon_{i, t} \ldots \ldots
$$


where

$T A C C_{i, t}=$ total current accrual of company $i$ in year $t$, in rupiah;

$$
=\left(O N I_{i, t}-O C F_{i, t}\right)
$$

$O N I_{i, t}=$ operating net income of company $i$ in fiscal year $t$, in rupiah;

$O C F_{i, t}=$ cash flow from operation of company $i$ in year $t$, in rupiah;

$A S_{i, t-1}=$ total asset of company $i$ by the end of fiscal year $t-1$, in rupiah;

$\triangle R E V_{i, t}=$ change in revenue of company $i$ at the end of fiscal year $t$, in rupiah;

$\Delta A R_{i t}=$ change in account receivables of company $i$ at the end of fiscal year $t$, in rupiah;

$P P E_{i t}=$ book value of fixed assets of company $i$ in year $t$, in rupiah;

$\varepsilon_{i t} \quad=$ residual $(D A)$.

Residual value of this modified Jones model estimation is free from company's condition variable ${ }^{22}$, thus this residual value would represent the magnitude of accrual discretionary or abnormal accruals $(D A)$. $D A$ will be the dependent variable in regression model of this research. $D A$ value can be positive, negative, or $0^{21,22} . D A$ with a positive value shows that accrual earnings management will increase net income. On the contrary, $D A$ with negative value shows that accrual earnings management will decrease net income. Company that does not engage in earnings management will have $D A$ with the value of 0 .

\section{Fiscal Incentive}

Fiscal incentive that is offered for listed companies is income tax rate reduction by $5 \%$. This incentive will benefit the company by reducing its income tax and creating tax saving. Based on $\mathrm{He}^{8}$, the amount of tax saving the company can have is the difference between income tax expense with the normal rate and the actual income tax expense with the reduced rate. Whereas the tax saving rate (TAXSAV) is calculated with equation below:

where

$$
T A X S A V=\frac{\text { pretax income-income tax expense }}{\text { net income }} \ldots . . .
$$

TAXSAV

pretax income

income tax expense

net income

$\mathrm{He}^{8}$ argumented that TAXSAV will represent how far tax saving contributes to an increase of a company's reported net income.

This research will also use a dummy variable (TAXSAV_DUM). A value of 1 will be given to companies that receive the reduced tax rate and 0 will be given to companies that do not. This variable will be an alternative to see how earnings management is affected upon receiving the facility.

\section{Multivariate Regression}

To see the correlation between abnormal acruals and tax saving, the regression models used are as follow:

$$
D A=\beta_{0}+\beta_{1} T A X S A V+\gamma_{1} M K T+\gamma_{2} L E V+\gamma_{3} S I Z E+\gamma_{4} E X P+\gamma_{5} R O A+\gamma_{6} \Delta R O A+\varepsilon \ldots \ldots \text { (3) }
$$

and

$$
D A=\beta_{0}+\beta_{1} T A X S A V_{-} D U M+\gamma_{1} M K T+\gamma_{2} L E V+\gamma_{3} S I Z E+\gamma_{4} E X P+\gamma_{5} R O A+\gamma_{6} \Delta R O A+\varepsilon
$$

$D A$ or abnormal accruals is the dependent variable which is the residual of cross-section estimation on equation (1). TAXSAV and TAXSAV_DUM are the independent variables which are resulted from equation (2). Based on the hypothesis, the correlation between TAXSAV and DA will be negative which shows the bigger (smaller) TAXSAV value is, the lower (higher) $D A$ value will be. This regression result will prove whether the higher fiscal incentives received by a company will lower its earnings management or otherwise. In this regression model, there will be six control variables, which are market-to-book ratio $(M K T)$, leverage ratio ( $L E V)$, company size (SIZE), capital intensity ratio $(E X P)$, return on asset ratio $(R O A)$, and absolute value of change in $R O A(\triangle R O A)$.

\section{RESULTS AND DISCUSSIONS}

This research uses purposive sampling method with following criterias:

Table.1. Result of Sample Selection

\begin{tabular}{lc}
\hline Description & Total \\
\hline Total listed companies on IDX over the period of 2008-2014 & 3104 \\
Total companies on the finance and mining industries over the period of 2008-2014 & $(500)$ \\
Total companies that are subject to final tax only over the period of 2008-2014 & $(41)$ \\
Total companies with uncomplete financial report information over the period of 2008-2014 & $(555)$ \\
\hline Total companies used as final sample & 2008 \\
\hline
\end{tabular}


After excluding outliers, the final sample is 2008 which consists of 346 companies in the period of 7 years. Samples are arranged into unbalanced panel data with different amount of companies in each years due to an increasing trend of companies conducting IPO over the period.

Table.2. Descriptive Statistics

\begin{tabular}{lrrrr}
\hline Variable & Std. Dev. & \multicolumn{1}{c}{ Mean } & Min. & \multicolumn{1}{c}{ Max. } \\
\hline DA & 0.3868 & -0.0058 & -8.98 & 8.59 \\
TAXSAV & 1.7191 & 1.2279 & -10.78 & 44.94 \\
TAXSAV_DUM & 0.3418 & 0.1350 & 0 & 1 \\
MKT & 0.0071 & 0.0022 & -0.04 & 0.24 \\
LEV & 0.3660 & 0.2780 & 0 & 5.34 \\
SIZE & 1.7447 & 21.0927 & 14.99 & 26.17 \\
EXP & 0.2539 & 0.3781 & 0 & 0.99 \\
ROA & 1.3818 & 5.5622 & 4.08 & 7.04 \\
DELTA_ROA & 0.7100 & 2.3687 & 1.62 & 3.14 \\
\hline
\end{tabular}

The descriptive statistics results show that the data is dispersed in a narrow range as can be seen from the standard deviation index. The mean of accrual discretionaries is -0.0058 which shows that sample companies in average engage in earnings management, although the magnitude is small. The negative value indicates that minimizing net income is one way to manage earnings, and it also represents that in average companies have lower change in revenue compared to change in account receivables. As mentioned in equation (1) that $\frac{\Delta R E V_{i, t}-\triangle A R_{i t}}{A S_{i, t}}$ will result in a negative value when company prefer to hold discretion in account receivables by recognizing receivables too early in the current fiscal year. Negative value can also be generated from the decrease in current year net income compared to prior year due to discretion i.e. postponing revenue recognition, or without discretion i.e. decrease in sales. The range of discretionary accruals in sample is -8.98 to 8.59 . The wider the range is from 0 , the bigger the magnitude of earnings management conducted by sample companies. The negative and positive signs show the way companies engage in earnings management, whether through decreasing or increasing net income.

Tax saving rate (TAXSAV) have a positive value with mean of $122.79 \%$ which shows that in average sample companies have sufficient tax savings. Tax savings dummy (TAXSAV_DUM) is also in a positive value of $13.50 \%$ which shows the percentage of sample companies that receive the tax rate reduction facility. All control variables (MKT, LEV, SIZE, EXP, ROA, DELTA_ROA) have positive mean values.

Based on classical tests, regression model (3) and (4) are free from multicollinearity, but are indicated to have heteroskedasticity and autocorrelation. To eliminate these effects, the model will be regressed using feasible generalized least square (FGLS) method. The results from FGLS regression are shown on table below:

Table.3. Regression Results for Model (3)

\begin{tabular}{|c|c|c|c|c|}
\hline \multicolumn{5}{|c|}{$D A=\beta_{0}+\beta_{1} T A X S A V+\gamma_{1} M K T+\gamma_{2} L E V+\gamma_{3} S I Z E+\gamma_{4} E X P+\gamma_{5} R O A+\gamma_{6} \Delta R O A+\varepsilon$} \\
\hline Variable & Hypothesis & Coef. & z-Statistics & P-value \\
\hline Intercept & & -0.2818 & -2.52 & 0.012 \\
\hline$T A X S A V$ & $(-)$ & -0.0036 & -0.72 & 0.472 \\
\hline$M K T$ & $(+)$ & -1.3269 & -1.09 & 0.275 \\
\hline$L E V$ & $(+)$ & -0.0478 & -1.98 & $0.048^{*}$ \\
\hline SIZE & $(-)$ & 0.0118 & 2.34 & $0.019^{*}$ \\
\hline$E X P$ & $(-)$ & -0.0785 & -2.25 & $0.024^{*}$ \\
\hline$R O A$ & $(+)$ & 0.0141 & 2.19 & $0.029^{*}$ \\
\hline DELTA_ROA & $(+)$ & -0.0005 & -0.04 & 0.965 \\
\hline Within-R $\left.{ }^{2} \%\right)$ & 4.89 & & & \\
\hline
\end{tabular}

Equation (4) uses dummy for tax savings variable. The regression results are shown below:

Table.4. Regression Results for Model (4)

\begin{tabular}{|c|c|c|c|c|}
\hline \multicolumn{5}{|c|}{$D A=\beta_{0}+\beta_{1} T A X S A V_{-} D U M+\gamma_{1} M K T+\gamma_{2} L E V+\gamma_{3} S I Z E+\gamma_{4} E X P+\gamma_{5} R O A+\gamma_{6} \Delta R O A+\varepsilon$} \\
\hline Variable & Hypothesis & Coef. & z-Statistics & P-value \\
\hline Intercept & & -0.2888 & -2.50 & 0.013 \\
\hline TAXSAV DUM & $(-)$ & -0.0041 & -0.15 & 0.877 \\
\hline
\end{tabular}




\begin{tabular}{lcccc}
\hline$M K T$ & $(+)$ & -1.3411 & -1.10 & 0.270 \\
LEV & $(+)$ & -0.0477 & -1.97 & $0.048^{*}$ \\
SIZE & $(-)$ & 0.0120 & 2.26 & $0.024^{*}$ \\
$E X P$ & $(-)$ & -0.0784 & -2.25 & $0.025^{*}$ \\
ROA & $(+)$ & 0.0140 & 2.16 & $0.031^{*}$ \\
DELTA_ROA & $(+)$ & 0.0002 & 0.02 & 0.984 \\
\hline Within-R ${ }^{2}(\%)$ & 4.90 & & & \\
\hline
\end{tabular}

\section{Analysis}

Based on the regression results in Table 3, the independent variable TAXSAV has an insignificant negative correlation with the dependent variable $D A$. This result is consistent with $\mathrm{He}^{8}$, who found that the higher (lower) a company's tax saving is, the less (more) likely a company is to be engaged in earnings management. Both findings show that the correlations are insignificant due to the more dominant variation of the cross-section effect compared to the time-series effect that will influence the estimation of panel data regression. The variation of the time-series will increase when there is a significant change in the acceptance of the facility for each sample company during the observed period. Based on the samples in China ${ }^{8}$ and Indonesia, when a company has received the facility in one fiscal year, it tends to keep receiving the facility in subsequent years.

In Indonesia, the requirement to be able to receive the facility is to trade a minimum of $40 \%$ of total issued shares in IDX. The change in share structure has to be reported to the Securities Administration Bureau each month based on Bapepam-LK Regulation No. X.H.1. The Securities Administration Bureau then issues a letter of acknowledgement that will be attached to the company's tax slip every year based on Ministry of Finance Regulation No. 238/2008. Bapepam-LK will then report to DGT the list of taxpayers that are qualified to receive the tax rate reduction facility in the reported fiscal year. The companies who have received the facility will lose the benefit when the public shareholders in one year become less than $40 \%$ of the total issued shares, they are owned by fewer than 300 shareholders, or there is one or a few shareholders that own more than $5 \%$ of the total issued shares. One condition where this issue can occur is when companies buy back their shares. However, the change of structure, as mentioned above, happens only in certain samples; thus, there is not much change in the recipient list in each fiscal year. The impact of this minimum change is that there is a limited variation in the time-series factor of TAXSAV which, in turn, generates an insignificant correlation to $D A$.

Based on the regression results in Table 4, independent variable TAXSAV_DUM shows consistent results with Table 3. The P-value coefficient is higher in model (4) (0.877) compared to in model (3) (0.472) due to the small percentage of sample companies that receive the facility, which is only $13.50 \%$ of all sample companies (see Table 2). This shows how TAXSAV_DUM has a more insignificant impact on accruals discretionary.

The low significance of the two independent variables shows that receiving the tax rate reduction facility has no impact on earnings management practices by listed companies in Indonesia. The rationale is that once a company sells $40 \%$ or more of its shares to the public and so receives the facility, it will be less likely to buy back its shares. By maintaining the share composition, the company will continue to receive the facility.

\section{CONCLUSION}

Based on the estimation results and the tests that have been conducted, we can conclude that the facility of company tax rate reduction based on GR No. 81/2007 and its amendment on GR 77/2013 have no impact on earnings management practices among listed companies in Indonesia. This finding does not prove the hypothesis that the more tax facilities a company receives, the less it is to engage in earnings management.

\section{Recommendation}

This research uses data in the period of 2008-2014, whereas the tax rate reduction facility was still applicable while this research was conducted in 2016. Further investigation is needed by including the list of facility recipients in 2015 since there is an increasing trend for more recipients. With an increasing number of recipients over the years included in the sample, we hope that it will increase the level of significance of the regression model. In addition, further research should also include other fiscal facilities that have been applied in the current year, such as tax allowance, tax holiday, and tax amnesty. 


\section{APPENDIX A. SUMMARY OF DEFINITION AND VARIABLES}

\begin{tabular}{|c|c|}
\hline Variable & Definition \\
\hline$D A$ & $\begin{array}{l}\text { Abnormal accruals for one sample company in one fiscal year, calculated by using modified Jones model with } \\
\text { cross-section parameter. }\end{array}$ \\
\hline$T A X S A V$ & $\begin{array}{l}\text { Tax saving rate, calculated by substracting company's commercial taxable income with commercial income tax } \\
\text { expense and divided by commercial net income. }\end{array}$ \\
\hline$T A X S A V \_D U M$ & $\begin{array}{l}\text { Dummy value for companies that receive tax rate reduction facility (given a score of } 1 \text { ) and companies that do not } \\
\text { receive the facility (given a score of } 0 \text { ). }\end{array}$ \\
\hline$M K T$ & The growth rate of company value, calculated by using market value for common shares divided by the book value. \\
\hline$L E V$ & $\begin{array}{l}\text { Leverage ratio of company, calculated by accumulating all short-term and long-term debt and divided by total } \\
\text { assets. }\end{array}$ \\
\hline SIZE & Company size, calculated by using natural logarithm of total assets. \\
\hline EXP & $\begin{array}{l}\text { Capital intensity ratio that represents company's asset structure, calculated by dividing total fixed assets with total } \\
\text { assets. }\end{array}$ \\
\hline$R O A$ & Return on assets ratio, calculated by dividing net income with total assets. \\
\hline$\triangle R O A$ & $\begin{array}{l}\text { Growth of ROA in absolut figure, calculated by substracting net income year } \mathrm{t}_{\text {with }} \mathrm{t}-1 \text { and divided by total assets } \\
\text { year } \mathrm{t}_{\mathrm{t}} \text { and } \mathrm{t} \text {. }\end{array}$ \\
\hline
\end{tabular}

\section{REFERENCES}

[1] Directorate General of Taxation. Fasilitas dan Insentif Pajak Penghasilan Indonesia, Edisi Ke-2. Directorate General of Taxation, Jakarta (2013).

[2] H Pamungkas. Fasilitas tarif pajak penghasilan untuk perusahaan terbuka. Binus Business Review, 3(1) (2012) 1-14.

[3] SH Teoh, I Welch, TJ Wong. Earnings management and the underperformance of seasoned equity offerings. Journal of Financial Economics, 50(1) (1998) 63-99.

[4] L Shivakumar. Do firms mislead investors by overstating earnings before seasoned equity offerings?. Journal of Accounting and Economics, 29(3) (2000) 339-371.

[5] PM Dechow, CM Schrand. Earnings Quality. The Research Foundation of CFA Institute, Virginia (2004).

[6] K Nagata, T Hachiya. Earnings management and the pricing of initial public offering. Review of Pacific Basin Financial Markets and Policies, 10(4) (2007) 541-559.

[7] K Nagata. Does earnings management lead to favorable IPO prive formation or further underpricing? Evidence from Japan. Journal of Multinational Financial Management, 23(4) (2013) 301-313.

[8] G He. Fiscal support and earnings management. The International Journal of Accounting, 51(1) (2011) 57-84.

[9] A Alesina, S Ardagna. Large charges in fiscal policy: Taxes versus spending. National Bureau of Economic Research, 24 (2010) 35-68.

[10] A Alesina, S Ardagna, R Perotti, F Schiantarelli. Fiscal policy, profits, and investment. National Bureau of Economic Research Working Paper Series, 7207 (1999).

[11] KA Hasset, RG Hubbard. Tax policy and business investment. Handbook of Public Economics, 3 (2002) 1294-1338.

[12] S Sarkar. Attracting private investment: Tax reduction, investment subsidy, or both?. Economic Modelling, 29(5) (2012) $1780-1785$.

[13] J Edgerton. Investment incentives and corporate tax asymmetries. Journal of Public Economics, 94(11-12) (2010) 936-952.

[14] MC Jensen, WH Mackling. Theory of the firm: Managerial behavior, agency costs and ownership structure. Journal of Financial Economics, 3(4) (1976) 305-360.

[15] RW Scott. Financial Accounting Theory, $2^{\text {nd }}$ Edition. Prentice Hall, New Jersey (2000).

[16] I Zagers-Mamedova. The Effect of Leverage Increases on Real Earnings Management. Thesis, Erasmus University (2008).

[17] MF McNichols. Research design issues in earnings management studies. Journal of Accounting and Public Policy, 19(4-5) (2000) 313345.

[18] H Yamashita, K Otogawa. Do Japanese Firms Manage Earnings in Response to Tax Rate Reduction in the Late 1990s?. Working Paper, Tokyo University of Science (2007).

[19] T Zeng. Earnings management around tax reduction: Evidence from China's 2007 corporate tax reform. Asian Review of Accounting, 22(3) (2014) 304-317.

[20] D Burgstahler, I Dichev. Earnings management to avoid earnings decreases and losses. Journal of Accounting and Economics, 24(1) (1997) 99-126.

[21] IM Haw, B Hu, LS Hwang, W Wu. Ultimate ownership, income management, and legal and extra-legal institutions. Journal of Accounting Research, 42(2) (2004) 423-462.

[22] L Sun, S Rath. An empirical analysis of earnings management in Australia. International Journal of Social, Behavior, Educational, Economic, Business and Industrial Engineering, 3(7) (2009) 1682-1698.

[23] I Geraldina. Preferensi manajemen laba akrual atau manajemen laba riil dalam aktivitas tax shelter. Jurnal Akuntansi dan Keuangan Indonesia, 10(2) (2013) 206-224. 